\title{
Trichomycetes from lentic and lotic aquatic habitats in Ontario, Canada
}

\author{
D.B. Strongman and Merlin M. White
}

\begin{abstract}
Fungi and protists make up an ecological group, trichomycetes, that inhabit the guts of invertebrates, mostly aquatic insects. Trichomycetes are reported herein from arthropods collected in lotic habitats (fast flowing streams) and lentic environments (ponds, ditches, seeps, and lakes) from 11 sites in Algonquin Park and 6 other sites in Ontario, Canada. Thirty-two trichomycete species were recovered, including 7 new species: Legeriomyces algonquinensis, Legeriosimilis leptocerci, Legeriosimilis whitneyi, and Paramoebidium umbonatum are described from mayfly nymphs (Ephemeroptera); Pennella digitata and Glotzia incilis from black fly and midge larvae (Diptera), respectively; and Arundinula opeongoensis from a crayfish (Crustacea). Legeriomyces rarus Lichtw. \& M.C. Williams and Stachylina penetralis Lichtw. are new North American records, and seven species are documented for the first time in Canada. More common and widely distributed trichomycete species such as Harpella melusinae Léger \& Duboscq and Smittium culicis Manier, were also recovered. Most previous studies on trichomycetes have been done primarily in lotic environments but clearly lentic systems (e.g., ponds and lakes) harbour diverse arthropod communities and further exploration of these habitats will continue to increase our knowledge of trichomycete diversity.
\end{abstract}

Key words: Amoebidiales, Eccrinales, Harpellales, insect fungal endobionts, symbiotic protista.

Résumé : Les champignons et les protistes comportent un groupe écologique, les trichomycètes, qui habitent les intestins de la plupart des insectes aquatiques. Les auteurs rapportent des ttrichomycètes provenant d'arthropodes vivants dans des habitats lotiques (cours d'eau rapides) et des environnements lentiques (étangs, fossés, suintement et lacs) récoltés sur 11 sites dans le parc Algonquin et six autres sites en Ontario, au Canada. On a trouvé 33 espèces de trichomycètes, incluant sept nouvelles espèces pour l'Amérique du Nord: Lageriomyces algonquinensis, Lageriosimilis leptocerci, Lageriosimilis whitneyi et Paramoebidium umbonatum, décrits à partir de nymphes d'éphémères (Ephemeroptera); Pennella digitata et Glotzia incilis à partir de mouches noires et de brûlots (Diptera) respectivement; et Arundinula opeongoensis à partir d'un écrevisse (Crustacea). Le Lageriomyces rarus Lichtw. \& M. C. Williams et le Stachylina penetralis Lichtw. Sept espèces sont répertoriées pour la première fois au Canada. On a également retrouvé des espèces de trichomycètes communes et largement distribuées, comme l'Harpella melusinae Léger \& Duboscq et le Smittum culicis Manier. La plupart des études antécédentes sur les trichomycètes ont été conduites surtout en environnements lotiques, mais il est clair que les systèmes lentiques (étangs et lacs) comportent diverses communautés d'arthropodes et que d'autres explorations de ces habitats vont permettre d'augmenter notre connaissance de la diversité des trichomycètes.

Mots-clés : Amaoebidiales, Eccrinales, Harpellales, champignons endosymbiontes des insectes, protistes symbiotiques.

[Traduit par la Rédaction]

\section{Introduction}

Canada has a wide variety of freshwater aquatic habitats such as lakes, ponds, swamps, rivers, and streams, making up extensive watersheds. Information on Canada's immense hydrologic diversity is available from Environment Canada.

One region in Canada where freshwater aquatic systems have been studied and well characterized is within Algonquin Park, a part of the Ontario provincial parks system. The park is $7725 \mathrm{~km}^{2}$ of managed wilderness in the Boreal Shield ecoregion, and is composed of terrestrial mixedwood

Received 18 June 2008. Published on the NRC Research Press Web site at botany.nrc.ca on 5 December 2008.

D. Strongman. ${ }^{\mathbf{1}}$ Biology Department, Saint Mary's University, 923 Robie Street, Halifax, NS B3H 3C3, Canada.

M.M. White. Department of Biological Sciences, 1910

University Drive, Boise State University, Boise, ID 83725-1515, USA.

${ }^{1}$ Corresponding author (e-mail: doug.strongman@smu.ca). forest and aquatic systems, dominated by lakes, bogs, and swamps, connected by small streams (SBAA 2004-2005; Runtz 2008). Algonquin Park has been the site of a large number of long-term biological studies in both terrestrial and aquatic systems, mostly fish biology (Harkness Laboratory of Fisheries Research 1930-2009). Some studies on aquatic insects (e.g., black flies) have also been done in the park (Sprules 1947; Davies 1952; Hall and Ide 1987) and it has a rich aquatic insect fauna.

Certain insects and other arthropods in aquatic habitats house a diverse assemblage of symbiotic microorganisms in their digestive tract. Hibbett et al. (2007), in their taxonomic reevaluation of fungi and fungal-like organisms, recognized the polyphyletic nature of endobiotic microorganisms living in the guts of arthropods and recommended that the term "trichomycetes" be used to describe this ecological group composed of specific fungi and protists, traditionally classified in the Class Trichomycetes (Lichtwardt 1986). We adopt the Hibbett et al. (2007) interpretation and terminology here. Most data on trichomycete biodiversity come 
from studies in Europe (e.g., Britain, France, and Spain) and the United States. Other survey records, typically from one or a few short term trips, come from a wide variety of locations including Australia, China, Costa Rica, Japan, New Zealand Norway, South America, and Sweden (Lichtwardt 1986; Lichtwardt et al. 2001a).

Trichomycetes also have been reported from Atlantic Canada. Results of two surveys from the vicinity of St. John's, Newfoundland, both from mainly lotic habitats, have been published (Frost and Manier 1971; Lichtwardt et al. 2001b). A survey spanning 7 years reported trichomycetes from stoneflies at 14 lotic sites in Nova Scotia (Strongman and White 2006). Strongman (2007) described trichomycetes from aquatic insects collected from streams on Prince Edward Island. Adler et al. (2005) also noted the presence of Harpella melusinae Léger \& Duboscq in black fly larvae from the Magdalen Islands in the Gulf of St. Lawrence.

Potential trichomycete hosts in both lotic and lentic habitats include immature, nonpredaceous species of arthropods such as Ephemeroptera, Coleoptera, Diptera, Plecoptera, Trichoptera, and isopods (Merritt and Cummins 1996). Mosquito larvae, found in standing water of all types, are known hosts of gut fungi (Lichtwardt 1986; Lichtwardt et al. 2001a). However, extensive surveys for trichomycetes in standing waters are few. Lentic habitats are common on the Canadian landscape, so more collections of insects and other arthropods from these habitats should increase our understanding of trichomycetes and their distribution.

Other unique insect habitats that have been examined less frequently than streams or lakes, are freshwater seeps and similar moist terrestrial habitats (e.g., waterfall splash zones). These habitats often contain larval dipterans, such as midges, and trichomycetes (e.g., Harpellomyces spp.) are adapted to colonize the guts of insects that occur in these unique environments (Lichtwardt et al. 2001a).

We present the results of trichomycete surveys conducted from 2-7 May 2003 and 17-27 May 2004 in both lotic (streams) and lentic (ponds, lakes and ditches) systems, as well as seeps at road cuts in and near Algonquin Park, Ontario. Additional collections were made (in 2004) from four sites west of the park. This is the first report of trichomycetes from central Canada and is part of a larger project to record trichomycete biodiversity in North America (see also Strongman and White 2006; White et al. 2006b; Strongman 2007; Valle et al. 2008).

\section{Materials and methods}

Arthropods were collected from lentic systems including Opeongo Lake, ponds, ditches, as well as seeps on highway road cuts, in Algonquin Park. Lotic systems (streams) were also sampled both inside and outside the park. In all, invertebrates were collected from 11 sites in Algonquin Park (ALG), 2 sites near Algonquin Park (PAP and WHIT), and 4 sites southwest of the Park (ONT 1-4) (Table 1). Substrate characteristics in the lentic environments were typically silty, with plant litter and live vegetation (e.g., grasses). Lotic substrates were rocky, ranging in size from large boulders to cobble and small stones. The water at all sites sampled in Algonquin Park ranged from $\mathrm{pH}$ 6.4-7. The water temperature typically was about $7{ }^{\circ} \mathrm{C}$ in running water and around $14{ }^{\circ} \mathrm{C}$ in standing water over the collecting periods from 2-7 May 2003 and 17-27 May 2004. The seeps on road cuts were characterized by a thin layer of water constantly trickling over the rock surface, often with algae and other organic matter. These habitats had mostly larvae of Tipulidae and Chironomidae. Larvae belonging to the dipteran families Chironomidae, Psychodidae, Stratiomyidae, Thaumaleidae, and Tipulidae were collected from splash zones around waterfalls at sites (ONT 2-4) west of the Park, on or near the Bruce Peninsula, Ontario.

In addition to dipterans, immature stages of insects from several families in the orders Ephemeroptera, Plecoptera, and Collembola, as well as a crustacean (crayfish) and terrestrial arthropods (millipedes) were dissected, and the trichomycetes in their digestive tracts documented. Specimens in water were collected with aquatic dip nets $(30 \mathrm{~cm}$ gape, $0.5 \mathrm{~mm}$ mesh) by disturbing the substrate by foot (kicksampling) and capturing the dislodged hosts in the net. Invertebrates also were hand-picked from rocks and plant material removed from aquatic habitats and from terrestrial vegetation adjacent to the aquatic sampling sites. Insect larvae were picked from seeps with soft-tip forceps (BioQuip, Rancho Dominguez, Calif.). Guts were dissected in drops of water in Petri plates, or on microscope slides, on the stage of a stereomicroscope equipped with a transmitted light source. Trichomycete thalli were teased out of the gut with fine-tipped forceps and insect pins mounted in pin vises (Grobet, Carlstadt, N.J.). Thalli were transferred to water on a microscope slide (wet mounted), examined for spores and other taxonomically significant characteristics with a compound microscope equipped with phase and differential interference contrast (Nomarski) optics. Micrographs (digital and film) were taken, either before or after semipermanent voucher slides were made by infiltrating specimens with a drop of lactophenol - cotton blue stain (200 g phenol, $0.5 \mathrm{~g}$ cotton blue stain, $400 \mathrm{~mL}$ glycerol, $200 \mathrm{~mL}$ lactic acid, and $200 \mathrm{~mL}$ distilled water) placed on the edge of the cover slip, then, after removing excess stain, sealing the edges of the cover slip with clear fingernail polish (Lichtwardt 1986; Lichtwardt et al. 2001a). All measurements given in the species descriptions below were made from material stained with lactophenol - cotton blue (see Kim and Adler (2007) for effects of staining on trichospore dimensions of a trichomycete). Where possible, the species were identified using the LUCID keys for trichomycetes available at the University of Kansas Web site (Lichtwardt 2004). Type specimens for all new species were deposited at the National Mycological Herbarium, Agriculture and Agrifoods Canada, Ottawa, Ontario (DAOM). Additional voucher specimens of some of the new taxa, as well as other species reported, are available from the authors. Intact host vouchers (where available) were deposited at the Canadian National Collection of Insects, Arachnids, and Nematodes, K.W. Neatby Building, Ottawa.

\section{Results}

Thirty-two species of trichomycetes, including 7 new species described below, were collected from the 17 sites in Ontario (Tables 1 and 2). Fungal and protistan species are represented in the collections, which came from immature 
Table 1. Description of Ontario sites with collection dates and GPS coordinates.

\begin{tabular}{|c|c|c|c|}
\hline Collection codes* & Site description & Collection dates & Coordinates \\
\hline ALG 1 & Outflow at Costello Lake, under Opeongo Rd., Algonquin Park (ALG) & 2, 5 May 2003 & $\mathrm{~N}^{\prime} 5^{\circ} 35.96^{\prime}, \mathrm{W} 078^{\circ} 19.83^{\prime}$ \\
\hline ALG 8 & Same as ALG 1 & 17, 18 May 2004 & \\
\hline ALG 2 & Slow moving stream flowing into beaver pond beside Opeongo Rd., ALG & 2 May 2003 & $\mathrm{~N} 45^{\circ} 36.16^{\prime}, \mathrm{W} 078^{\circ} 20.10^{\prime}$ \\
\hline ALG 11 & Same as ALG 2 & 19 May 2004 & \\
\hline ALG 3 & Fast flowing stream draining beaver pond beside Opeongo Rd., ALG & 3, 4, 7 May 2003 & $\mathrm{~N} 45^{\circ} 36.19^{\prime}, \mathrm{W} 078^{\circ} 20.19^{\prime}$ \\
\hline ALG 9 & Same as ALG 3 & 17, 19 May 2004 & \\
\hline ALG 21 & Same as ALG 3 & 21 May 2004 & \\
\hline ALG 4 & Marshy area below small parking lot on Opeongo Rd., ALG & 5, 6 May 2003 & $\mathrm{~N}^{\prime} 5^{\circ} 36.42^{\prime}, \mathrm{W} 078^{\circ} 20.30^{\prime}$ \\
\hline ALG 14 & Same as ALG 4 & 19, 21 May 2004 & \\
\hline ALG 5 & Seep on road cut, Hwy 60 at Brewer Lake, ALG & 17, 21 May 2004 & $\mathrm{~N} 45^{\circ} 35.27^{\prime}, \mathrm{W} 078^{\circ} 18.04^{\prime}$ \\
\hline ALG 6 & Ragged falls, at base of falls near path from parking lot, ALG & 17 May 2004 & $\mathrm{~N} 45^{\circ} 23.43^{\prime}, \mathrm{W} 078^{\circ} 54.41^{\prime}$ \\
\hline ALG 7 & Small stream beside Hwy 60, $40 \mathrm{~km}$ west of Opeongo Rd., ALG & 17 May 2004 & $\mathrm{~N} 45^{\circ} 28.42^{\prime}, \mathrm{W} 078^{\circ} 46.29^{\prime}$ \\
\hline ALG 10 & Beaver pond, Opeongo Rd., ALG & 19 May 2004 & $\mathrm{~N} 45^{\circ} 36.20^{\prime}, \mathrm{W} 078^{\circ} 20.17^{\prime}$ \\
\hline ALG 12 & Same as ALG 10 & 20 May 2004 & \\
\hline ALG 20 & Same as ALG 10 & 23 May 2004 & \\
\hline ALG 15 & Opeongo Lake, ALG & 19 May 2004 & $\mathrm{~N} 45^{\circ} 38.05^{\prime}, \mathrm{W} 078^{\circ} 21.84^{\prime}$ \\
\hline HARK 1 & Same as ALG 15 & 7 May 2003 & \\
\hline ALG 18 & Seep on road cut on Hwy 60, inside ALG just west of Whitney & 21 May 2004 & $\mathrm{~N} 45^{\circ} 30.89^{\prime}, \mathrm{W} 078^{\circ} 15.69^{\prime}$ \\
\hline ALG 19 & Marsh beside Opeongo Rd., ALG & 23 May 2004 & $\mathrm{~N} 45^{\circ} 37.01^{\prime}, \mathrm{W} 078^{\circ} 39.94^{\prime}$ \\
\hline PAP (ALG 16) & Papineau Cr., on Hwy 62 to Maple Leaf & 21 May 2004 & $\mathrm{~N} 45^{\circ} 17.60^{\prime}, \mathrm{W} 077^{\circ} 48.87^{\prime}$ \\
\hline ONT 1 & Guelph, small, pebbly drainage surrounded by marshy area & 27 May 2004 & $\mathrm{~N} 43^{\circ} 24.69^{\prime}, \mathrm{W} 080^{\circ} 07.31^{\prime}$ \\
\hline ONT 2 & Rock Chapel Gorge, splash zone at waterfall & 27 May 2004 & $\mathrm{~N} 43^{\circ} 17.44^{\prime}, \mathrm{W} 079^{\circ} 56.23^{\prime}$ \\
\hline ONT 3 & Spencer Gorge, splash zone at waterfall & 27 May 2004 & $\mathrm{~N} 43^{\circ} 16.77^{\prime}, \mathrm{W} 079^{\circ} 58.74^{\prime}$ \\
\hline ONT 4 & Seep from spring at road cut near entrance of Inglis Falls conservation area & 27 May 2004 & $\mathrm{~N} 44^{\circ} 31.36^{\prime}, \mathrm{W} 080^{\circ} 56.01^{\prime}$ \\
\hline WHIT (ALG 22) & Madawaska River running through Whitney, below Hwy 60 & 3 May 2003 & $\mathrm{~N} 45^{\circ} 29.66^{\prime}, \mathrm{W} 078^{\circ} 14.04^{\prime}$ \\
\hline
\end{tabular}

*Collection codes refer to collections done in 2003 and 2004, some at the same site on different dates. 
stages of insects and adult millipedes, as well as a crustacean host (crayfish) (Table 2). Legeriomyces rarus Lichtw. \& M.C. Williams and Stachylina penetralis Lichtw. are new continental records, and seven other species are reported for the first time in Canada (Table 2). Eighteen species of trichomycetes were collected from insects in streams (lotic), 5 from hosts in lentic habitats, and 4 from insects that occurred in both environments. Three fungal species were found in dipterans from seeps on rock faces and two came from moist, terrestrial habitats, the latter from millipede and springtail hosts (Table 2).

\section{Taxonomy}

The new taxa described here include both protistan and fungal trichomycetes, defined in large part by the characteristics of various spore types that they each possess. The terminology differs between protistan and fungal members and also within the fungal orders: Harpellales and Asellariales. Descriptions of the various spore types, as well as details on other basic morphological features that define the taxa included in trichomycetes can be found in Lichtwardt (1986) and Lichtwardt et al. (2001a). We provide a brief summary of the main spore types relevant to the new species described herein: Harpellales produce asexual spores (trichospores) and many also produce a sexual spore, the zygospore, on a vegetative body (thallus). Lichtwardt et al. (2001a) describe four basic types (Types I-IV) of zygospores in the harpellids based on shape and method of attachment to the zygosporophore (support cells). Members of the Eccrinales reproduce asexually through the production of sporangiospores, which can occur in two forms (primary and secondary sporangiospores). According to Lichtwardt et al. (2001a) conclusive evidence of sexual reproduction has not been seen in this Order. The other protistan trichomycete group, the Amoebidiales (Lichtwardt 1986), disperse by amoebae (asexual). The amoebae encyst after release and in some species these cysts may undergo further development to produce cystospores that infest a new host when released (Lichtwardt et al. 2001a).

Arundinula opeongoensis M.M. White et Strongman sp. nov., Figs. 1-5

Thallus simplex, distaliter tumidus; cellula materna sporae 32-48.5 $\mathrm{mm} \times 6.5-10.5 \mu \mathrm{m}, 8$ pluresve nucleos continens, persistens; hapteron basale cupulatum 19-20 $\mu \mathrm{m} \times$ 11.5-13 $\mu \mathrm{m}$. Sporangiosporae secundariae rectangulares 30-37 $\mu \mathrm{m} \times 7-7.5 \mu \mathrm{m}$, extremitatibus rotundatis ubi liberatae. Sporangiosporae primariae in longitudine variabiles 5.5-11 $\mu \mathrm{m} \times 12-12.5 \mu \mathrm{m}$. Typi ambi sporangiosporarum in extremo distali thalli facti. In proctodaeo astacidearum aquae dulcis.

Thallus unbranched (Figs. 1-5), swollen distally; spore mother cell 32-48.5 $\mu \mathrm{m} \times 6.5-10.5 \mu \mathrm{m}$ (Fig. 3) with 8 or more nuclei, persistent; cup-shaped, basal holdfast 19$20 \mu \mathrm{m} \times 11.5-13 \mu \mathrm{m}$ (Figs. 4 and 5). Secondary sporangiospores rectangular, 30-37 $\mu \mathrm{m} \times 7-7.5 \mu \mathrm{m}$ (Fig. 2), rounded at the ends when released. Primary sporangiospores variable in length, 5.5-11 $\mu \mathrm{m} \times 12-12.5 \mu \mathrm{m}$ (Fig. 1), both primary and secondary sporangiospores produced at the distal end of the thallus. In hindgut of freshwater crayfish.
ETYMology: named for the collection site, Opeongo Lake, located in Algonquin Park, Ontario.

HOLOTYPE: microscope slide ALG-15-W1 prepared from the hindgut of a crayfish collected on 19 May 2004. Type deposited at DAOM (No. 240029).

навітAт: collected from Opeongo Lake (ALG 15) in Algonquin Park. Crayfish collected at other sites in Algonquin Park and from ONT 1 did not contain any trichomycetes.

COMMENTARY: Arundinula orconectis Lichtw. is the only other species from freshwater crustaceans (crayfish). However, Arundinula opeongoensis has a disk-like holdfast not present in A. orconectis, and A. orconectis has spherical secondary sporangiospores, and the primary sporangiospores are about twice as large (Lichtwardt 2004) as those of A. opeongoensis. The other five species in the genus are found in marine decapod crustaceans (e.g., crabs) and differ in thallus features, as well as sporangiospore shape and dimensions (Lichtwardt 2004).

Glotzia incilis Strongman et M.M. White sp. nov., Figs. 6-9

Thallus ad proctodaeum cellula basali bulbosa interius affixus; rami a cellula basali orientes, parce dividentes et ramos fertiles distales producentes. Cellulae genitales 6-8 in quoque ramo fertili, unaquaque trichosporam procreanti. Trichosporae anguste ellipticae, in mediano leniter tumidae, 21.5-26.5 $\mu \mathrm{m} \times 3.5-4.5 \mu \mathrm{m}$, appendicibus duabus brevibus (minus quam dimidium longitudinis sporae) et appendice tertia longiore quam trichospora instructae. Trichospora cum apice refractivo in preparationibus aut fucatis aut non fucatis. Zygosporae non inventae. In proctodaeo larvarum dixidarum.

Thallus attached to hindgut lining by a bulbous basal cell, branches arising from the basal cell dividing sparingly to give fertile branches distally (Fig. 6). Six to eight generative cells per fertile branch, each producing a trichospore (Fig. 7). Trichospores elliptical-elongate, with a slight medial swelling, $21.5-26.5 \mu \mathrm{m} \times 3.5-4.5 \mu \mathrm{m}$ with 2 short appendages (less than half the spore length) and a third appendage longer than the trichospore (Fig. 9), no collar. Trichospores with a refractive apex in both stained and unstained preparations. No zygospores found. In hindgut of meniscus midge larvae (Dixidae).

ETYMOLOGY: from the Latin incilis, meaning of a ditch, in reference to the habitat for the host midge larvae.

HOLOTYPE: microscope slide ALG-19-7 prepared from the hindgut of a meniscus midge (Dixidae) collected on 23 May 2004. Type deposited at DAOM (No. 240028).

навітАт: the fungus was collected from three larvae in a ditch containing cattails (Typha sp.) along Opeongo Road in Algonquin Park (ALG 19). Dixid larvae were collected at a second site (ALG 4) and these harboured Smittium culisetae Lichtw. (Table 2) but not Glotzia incilis.

COMMENTARY: Glotzia is the only genus of gut fungi that crosses the ordinal level of specificity that is observed in all the other trichomycetous fungi (Lichtwardt et al. 2001a). Glotzia centroptili Gauthier ex Manier \& Lichtw., the type species, and four other species are known from mayfly nymphs (Baetidae) while Glotzia plecopterorum Lichtw. 
Table 2. List of trichomycetes collected from each host and site in Ontario with known distribution of the trichomycetes (Lichtwardt 2004; Nelder et al. 2006).

\begin{tabular}{|c|c|c|c|}
\hline Species & Host & Site & Distribution* \\
\hline Arundinula opeongoensis & Crayfish & ALG 15 & \\
\hline Enterobryus euryuri ${ }^{\dagger}$ & Millipedes (Aphelaria sp., Narceus sp.) & ONT 3 & USA: IL \\
\hline Genistellospora homothallica $^{\dagger}$ & Black flies (Simuliidae) & ALG 1 & $\begin{array}{l}\text { Argentina, Armenia, Chile, Costa Rica, } \\
\text { England, Puerto Rico, Spain, USA }\end{array}$ \\
\hline Glotzia incilis & Meniscus midges (Dixidae) & ALG 19 & \\
\hline Graminella microspora $^{\dagger}$ & Mayflies (Baetidae) & ALG 10, PAP & Chile, Norway, Switzerland, USA: MT, TN \\
\hline Harpella melusinae & Black flies & PAP & Global \\
\hline Harpellomyces abruptus & Solitary midges (Anthroposopa americana, Thaumaleidae) & ONT 4 & Canada: NF \\
\hline Legeriomyces algonquinensis & Mayflies (Arthroplea bipunctata) & ALG 19 & \\
\hline Legeriomyces rarus ${ }^{\dagger}$ & Mayflies (Caenidae) & ONT 1 & Australia, Spain \\
\hline Legeriosimilis leptocerci & Mayflies (Siphlonurus sp.) & PAP & \\
\hline Legeriosimilis whitneyi & Mayflies (Ephemerella temporalis) & ALG 4, ALG 10, ALG 15, ALG 19, WHIT & \\
\hline Orchesellaria sp..$^{\dagger}$ & Springtail (Collembola) & ALG 7 & \\
\hline Orphella avalonensis & Stonefly (Leuctridae) & ALG 3, ALG 6 & Canada: NF, NS \\
\hline Paramoebidium curvum & Black flies & $\begin{array}{l}\text { ALG 2, ALG 3, ALG 7, ALG 10, ALG } \\
\text { 12, PAP }\end{array}$ & $\begin{array}{l}\text { Canada: NF, England, France, Sweden, } \\
\text { USA }\end{array}$ \\
\hline Paramoebidium spp. & $\begin{array}{l}\text { Mayflies (Baetidae, Ephemerellidae, Leptophlebiidae, } \\
\text { Siphlonurus sp.), black flies }\end{array}$ & All but ALG 5, ALG 13, ALG 18 & \\
\hline Paramoebidium umbonatum & Mayflies (Haprophlebia vibrans) & ALG 1 & \\
\hline Pennella simulii & Black flies & $\begin{array}{l}\text { ALG 1, ALG 2, ALG 3, ALG 7, ALG } \\
\text { 10, PAP }\end{array}$ & $\begin{array}{l}\text { Argentina, Canada: NF, NS, Costa Rica, } \\
\text { England, USA: CO, NC, SC, TN, WY }\end{array}$ \\
\hline Pennella digitata & Black flies & ALG 3, ALG 10 & \\
\hline Simuliomyces microsporus & Black flies & ALG 3, ALG 10 & Global \\
\hline Smittium alpinum ${ }^{\dagger}$ & Midges (Chironomidae) & ONT 4 & France, Sweden, Switzerland, USA: MT \\
\hline Smittium brevisporum & Midges & WHIT & Canada: PEI, Spain \\
\hline Smittium culicis & $\begin{array}{l}\text { Crane flies (Bactylolabis sp.), mosquitoes } \\
\text { (Culicidae), moth flies (Psychodidae), soldier flies } \\
\text { (Stratiomyidae) }\end{array}$ & $\begin{array}{l}\text { ONT 2, ONT 3, ALG 5, ALG 18, ALG } \\
\text { 19, PAP }\end{array}$ & Global \\
\hline 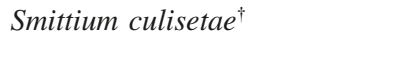 & Meniscus midges & ALG 4 & $\begin{array}{l}\text { Australia, Argentina, Brazil, France, } \\
\text { Hawaii, Japan, New Zealand, USA }\end{array}$ \\
\hline Smittium insulare & Mosquitoes & PAP & Canada: PEI \\
\hline Smittium mucronatum $^{\dagger}$ & Midges & ALG 7, ALG 10 & France, Norway, USA: CO \\
\hline Smittium simulii & Midges, mosquitoes & ALG 10, PAP & Global \\
\hline Smittium sp. & Midges, mayflies (Heptageniidae) & ALG 4, ONT 1 & \\
\hline Stachylina grandispora ${ }^{\dagger}$ & Midges & PAP & $\begin{array}{l}\text { Australia, Canada: PEI, England, Hawaii, } \\
\text { New Zealand, Sweden, USA }\end{array}$ \\
\hline Stachylina nana & Midges & ALG 1, ALG 2 & Canada: PEI, France \\
\hline Stachylina pedifer & Midges & ALG 5 & Canada: PEI, Norway, USA: MT, TN \\
\hline Stachylina penetralis & Midges & ONT 4 & China, France, Japan, Switzerland \\
\hline Stachylina sp. & Midges & ALG 1 , ALG 2, ALG 3 & \\
\hline
\end{tabular}

Note: Names in bold are new species described in this report from Ontario.

*Distribution of the species (Lichtwardt 2004; Nelder et al. 2006). IL (Illinois), USA (multiple states in the continental United States); USA: CO (Colorado), MT (Montana), NC (North Carolina), SC (South Carolina), TN (Tennessee), WY (Wyoming); Global (multiple continents); NF (Newfoundland); NS (Nova Scotia); PEI (Prince Edward Island).

${ }^{\dagger}$ New Canadian records. 
Figs. 1-5. Arundinula opeongoensis. Fig. 1. Primary sporangiospores (arrows) produced at the distal portion of the unbranched thallus. Fig. 2. Secondary sporangiospore (arrow) being released from the thallus. Fig. 3. Young thallus attached to the gut lining (arrow) with the persistent spore mother-cell (arrowhead). Fig. 4. Basal portions of thalli each with a cup-shaped holdfast (arrows). Fig. 5. Detached thallus with details of the cup-shaped holdfast (arrow). All Figs. from lactophenol - cotton blue stained specimens. Scale bars $=20 \mu \mathrm{m}$.
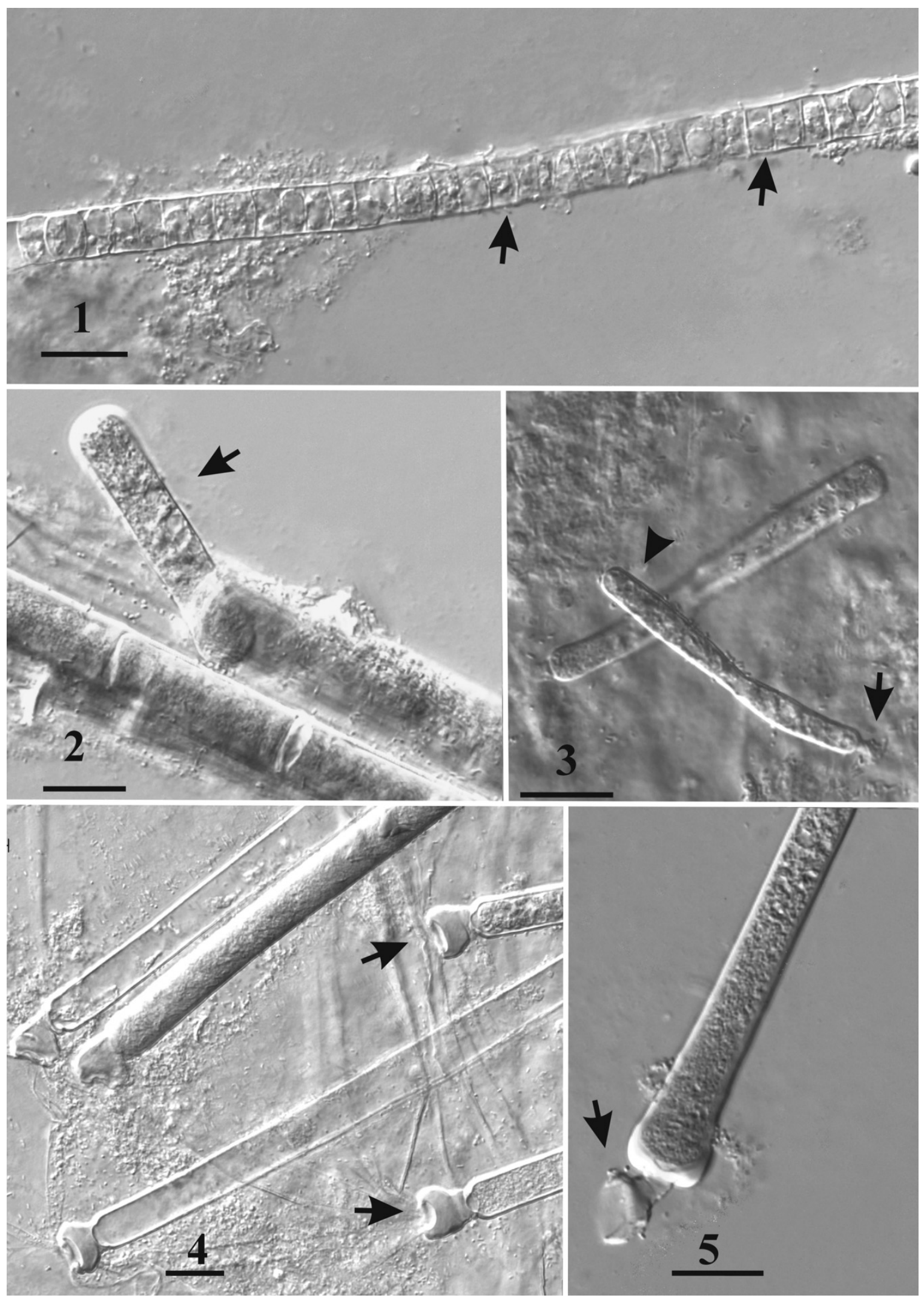

ate Ast ฟो:

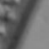


Figs. 6-9. Glotzia incilis. Fig. 6. Thallus with released trichospores (arrowheads). Thallus branches originating from a swollen basal cell (arrow). Fig. 7. Fertile branch with multiple trichospores at tip. Fig. 8. Holdfast showing swollen basal cell (arrow). Fig. 9. Trichospores with refractive tip and 3 appendages (arrows). All Figs. from lactophenol - cotton blue-stained specimens. Scale bars $=20 \mu \mathrm{m}$.
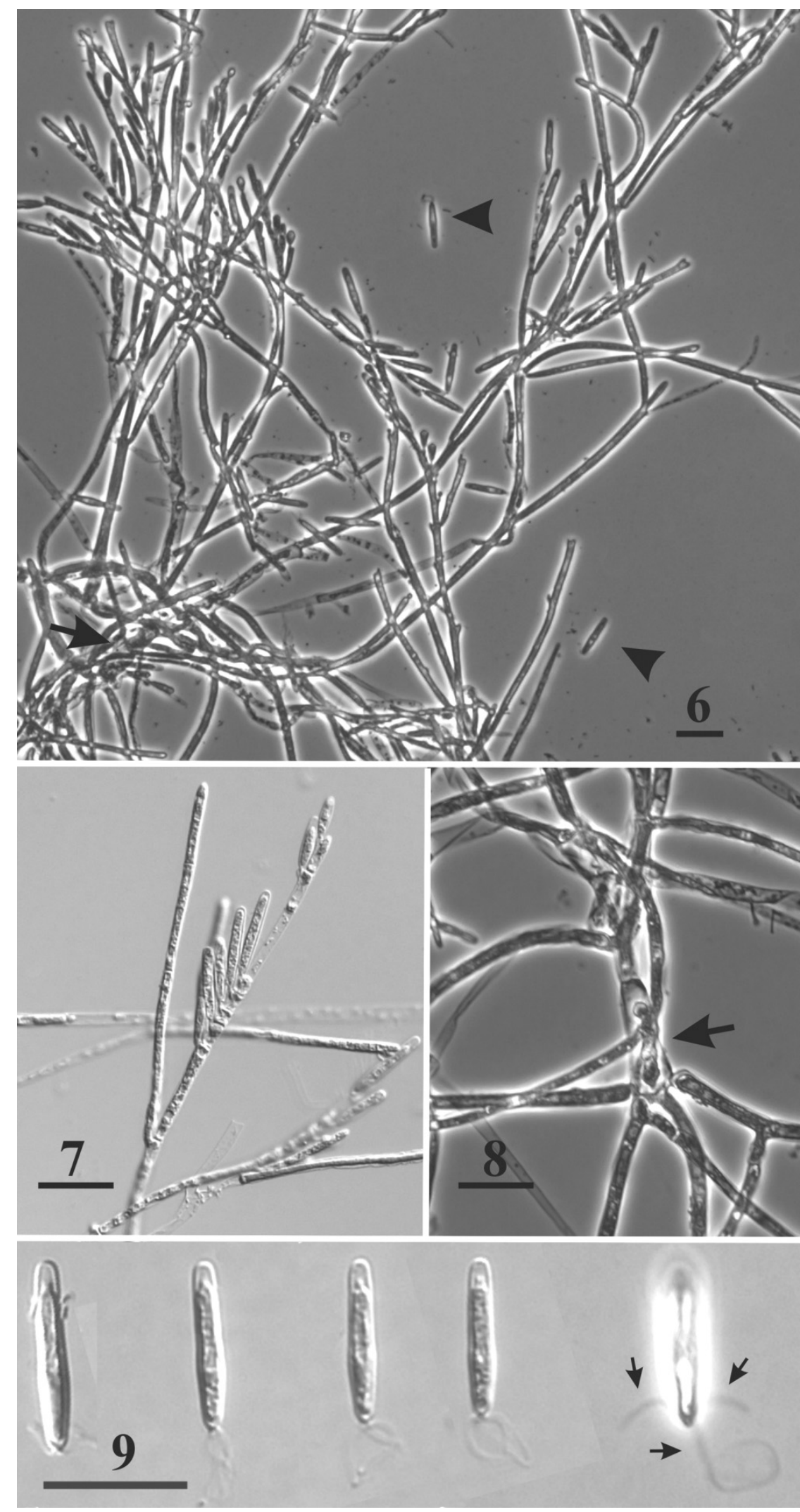
was described from a stonefly in New Zealand (Lichtwardt 2004). Glotzia incilis shares sufficient morphological features with other species in this genus, such as the holdfast structure, an enlarged basal cell and, specifically, three appendages on the trichospores, to place it in this taxon. However, the trichospores in $G$. incilis are shorter and are not cylindrical as in the other species (Lichtwardt 2004). We did not find any zygospores in specimens of $G$. incilis. All other species except G. plecopterorum and Glotzia tasmaniensis Lichtw. \& M.C. Williams (from baetid mayflies in Tasmania) have zygospores. Future collections that include zygospores of $G$. incilis and the other Glotzia species for which the sexual spore is unknown, will provide important characteristics for comparing these species from different hosts.

Legeriomyces algonquinensis Strongman et M.M. White sp. nov., Figs. 10 and 11

Thallus sparsus, sine haptero conspicuo; cellulae genitales 4-8 in quoque ramo fertili, unaquaque trichosporam leviter obpyriformem 19.5-21.5 $\mu \mathrm{m} \times 4.5-5.5 \mu \mathrm{m}$, appendicibus duabus instructam procreanti, sine collo. Zygosporae non inventae. Thalli ad proctodaeum heptageniidarum affixi.

Thallus sparse, no conspicuous holdfast; fertile branches with 4-8 generative cells per branch (Fig. 10), each producing a slightly obpyriform trichospore 19.5-21.5 $\mu \mathrm{m} \times 4.5-$ $5.5 \mu \mathrm{m}$, with two appendages (Fig. 11), no collar. No zygospores found. Thalli attached to the hindgut of mayflies (Heptageniidae).

ETYMOLOGY: in reference to the location where the fungus was collected, Algonquin Park.

HOLOTYPE: microscope slide ALG-19-1 prepared from the hindgut of a mayfly nymph Arthroplea bipunctata McDunnough (Heptageniidae) collected on 23 May 2004. Type deposited at DAOM (No. 240027).

НАВітAт: the fungus was dissected from the hindguts of $A$. $b i$ punctata nymphs collected from standing water in a ditch with cattails (Typha sp.) along Opeongo Road in Algonquin Park (ALG 19).

COMMENTARY: Legeriomyces algonquinensis has smaller trichospores than other species in the genus (Lichtwardt 2004), although the smallest trichospore size range reported for the trimorphic Legeriomyces aenigmaticus Lichtw. \& M.C. Williams $(14-23 \mu \mathrm{m} \times 3.5-5 \mu \mathrm{m})$ overlaps with L. algonquinensis (Lichtwardt 2004). Collections of L. algonquinensis were limited, but all trichospores were within a narrow size range $(19.5-21.5 \mu \mathrm{m} \times 4.5-5.5 \mu \mathrm{m})$ so there was no evidence to suggest dimorphism or trimorphism of the asexual spores in these collections. Further, the highly branched thallus in dense clumps, with a conspicuous holdfast composed of contorted cells as described for L. aenigmaticus by Lichtwardt and Williams (1983) is distinctly different than the sparsely branched thallus in L. algonquinensis. Legeriomyces aenigmaticus is rare and restricted in its distribution, having been collected only once from a small stream in Montana (Lichtwardt 2004). The type species, Legeriomyces ramosus Pouzar, is more widely distributed (recorded from Europe and USA), but the trichospores are larger and more obpyriform in shape (Lichtwardt 2004) than in L. algonquinensis. Trichospore shape and thallus characteristics of L. rarus are similar to L. algonquinensis, but the asexual spores of the former are larger, (25-)27(-31) $\mu \mathrm{m} \times 5.5-8 \mu \mathrm{m}$ (Lichtwardt 2004). Legeriomyces rarus has been reported from Australia and Spain (Williams and Lichtwardt 1993; Valle and Santamaria 2004) and we also collected it at ONT 1 (Table 2), the first report from Canada. Only a few gut fungi are reported from heptageniid hosts (Lichtwardt 2004) and the host for L. algonquinensis, A. bipunctata, occurs mostly in lentic habitats. This mayfly was not collected at other sites in Ontario.

\section{Legeriosimilis leptocerci M.M. White et Strongman sp. nov., Figs. 12-17}

Thallus ex ramis crassis multis, praeterea dividentibus et tenuiores ramos fertiles producentibus constructus. Cellulae genitales 1-4 in ramis terminalibus. Trichosporae 24$28 \mu \mathrm{m} \times 5.5-6 \mu \mathrm{m}$, leniter obpyriformes, appendicibus tribus basalibus tenuibus instructae, sine collo. Zygosporophora crassa 24-31 $\mathrm{mm}$ ×-11.5 $\mu \mathrm{m}$, hyphis conjugentibus directe exorientia. Zygosporae (Typus II) 67-73 $\mathrm{m} \times 12$ $14 \mu \mathrm{m}$, ad zygosporophorum oblique submediaque affixae. In proctodaeo nympharum siphlonuridarum.

Thallus composed of multiple thick branches, further dividing into thinner fertile branches. One to four generative cells on terminal branches (Fig. 12). Trichospores 24$28 \mu \mathrm{m} \times 5.5-6 \mu \mathrm{m}$ weakly obpyriform, with three thin, basal appendages (Figs. 13-15) and no collar. Stout zygosporophores 24-31 × 9-11.5 $\mu \mathrm{m}$ (Figs. 16 and 17), arise directly from conjugating hyphae. Zygospores (Type II), $67-73 \times 12-14 \mu \mathrm{m}$, attached to the zygosporophore obliquely and sub-medially (Fig. 17). In the hindgut of mayfly nymphs (Siphlonuridae).

ETYMOLOGY: from the Greek leptos meaning thin and kerkos meaning tail, referring to the thin appendages on the trichospore.

HOLOTYPE: microscope slide PAP-1 prepared from the hindgut of a Siphlonurus sp. nymph (Siphlonuridae) on 21 May 2004. Type deposited at DAOM (No. 240026).

навітAт: dissected from the hindgut of Siphlonurus sp. nymphs collected from Papineau Creek (PAP), a small stream flowing through a culvert under Hwy 62 near Maple Leaf, Ontario.

COMMENTARY: two previously described species, Legeriosimilis tricaudata M.C. Williams, Lichtw., M.M. White, \& Misra and Legeriosimilis europaeus M.M. White \& Lichtw. were recovered from siphlonurid mayflies (Lichtwardt 2004) and Legeriosimilis whitneyi (described below) was from an ephemerellid host. Compared with the other two species in siphlonurids, Legeriosimilis leptocerci has smaller trichospores and the zygospores are larger than those in L. tricaudata, but sexual spore dimensions overlap considerably with L. europaeus (Lichtwardt 2004). The very thin appendages on trichospores of $L$. leptocerci help to distinguish this species from the others in siphlonurids. The zygospores of L. whitneyi are smaller than those of L. leptocerci, and although the trichospores are very similar in size, the thin appendages in L. leptocerci also help differentiate between these two species. Both L. leptocerci and L. whitneyi lack obvious knobs associated with the appendages that are de- 
Figs. 10 and 11. Legeriomyces algonquinensis. Fig. 10. Thallus with sparse branching and fertile branches bearing trichospores. Fig. 11. Trichospores with submedial swelling and each bearing two appendages (arrowheads). Fig. 10 is living material, Fig. 11 is stained with lactophenol - cotton blue. Scale bars $=20 \mu \mathrm{m}$.
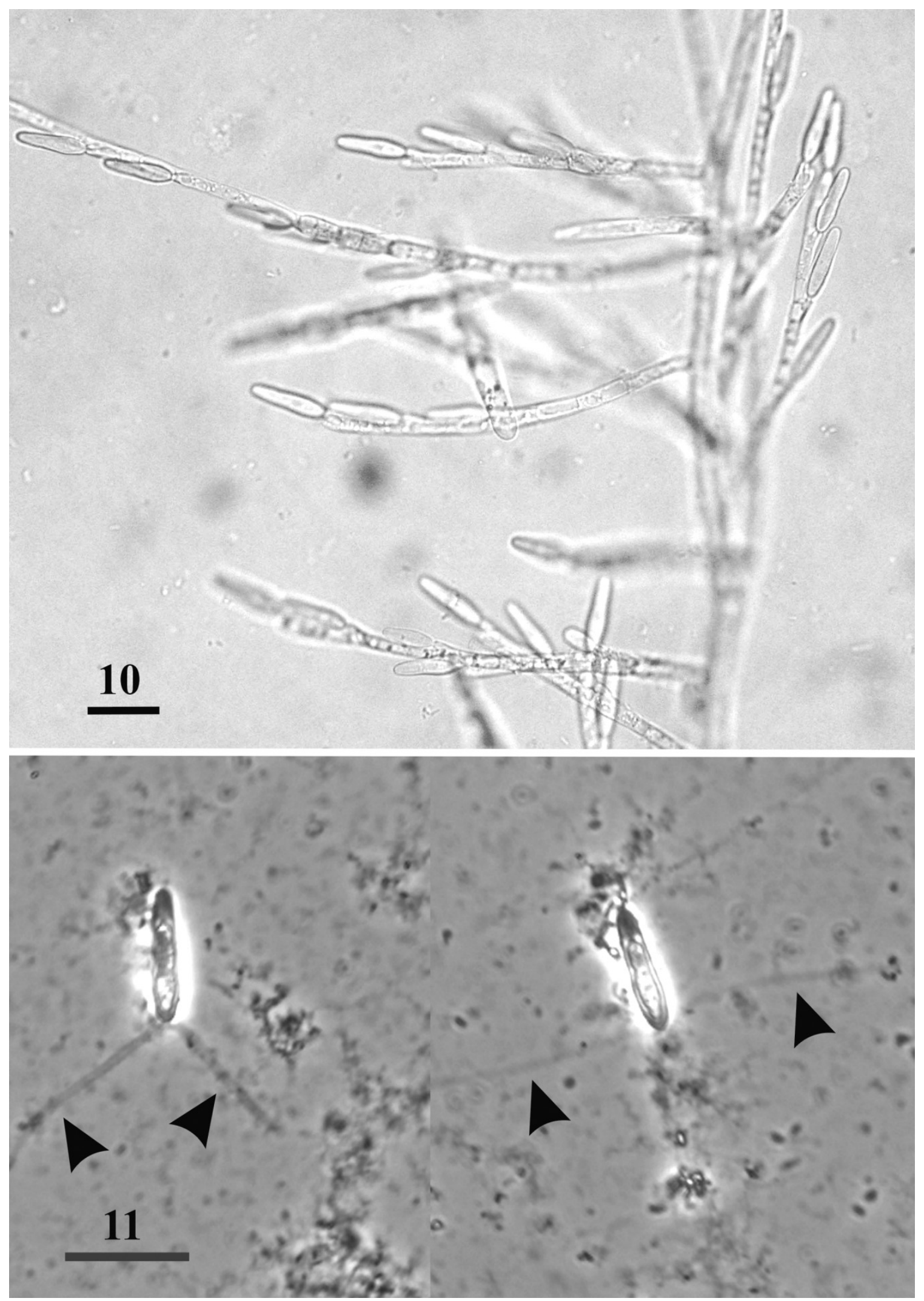
Figs. 12-17. Legeriosimilis leptocerci. Fig. 12. Portion of a sporulating thallus showing a thickened central axis with fertile branches. Fig. 13-15. Released trichospores with sub-medial swelling and 3 thin appendages (arrows). Fig. 16. A zygospore (Type II) on the zygosporophore (arrowhead). Fig. 17. Biconical zygospore (arrow) attached submedially to the stout zygosporophore (arrowhead). Figs. 12, 16, and 17 are living material, Figs. 13-15 are stained with lactophenol - cotton blue. Scale bars $=20 \mu \mathrm{m}$.

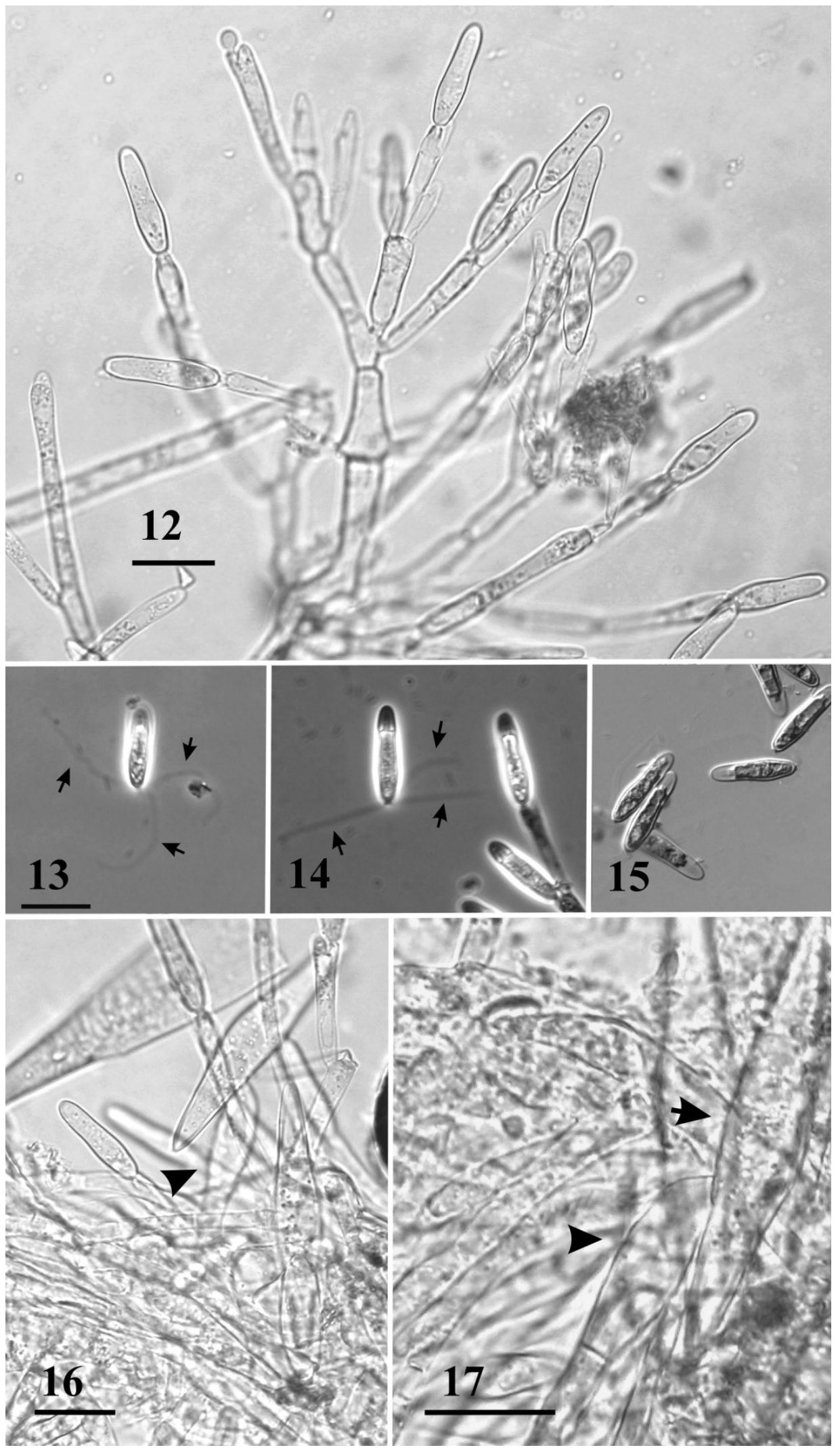


scribed for the other 2 species in this genus (Lichtwardt 2004). However, trichospore shape and presence of 3 appendages, zygospore shape and arrangement on the zygosporophore, as well as thallus characteristics suggest that both these species belong in the genus Legeriosimilis.

Legeriosimilis whitneyi Strongman et M.M. White sp. nov., Figures 18-21

Thallus duabus cellulis basalibus successivis tumidis 20$30 \mu \mathrm{m} \times 7-9 \mu \mathrm{m}$, vulgo instructus, ad proctodaeum interius secretione tenaci cellulae hapteroideae affixus. Rami a cellulis basalibus praeterea ramificantes, sporas distaliter ferentes. Trichosporae leniter obpyriformes, sine collo, 20$26.5 \mu \mathrm{m} \times 4.5-6 \mu \mathrm{m}$, appendices tres crassas longitudine aequales ferentes. Cellulae genitales 6-8 in quoque ramo fertili, longitudine ut minimum dimidium longitudinis sporae factae. Conjugatio cellularum contiguarum cellulam tumidam procreans, qua oritur zygosporophorum (13-17 $\mu \mathrm{m} \times$

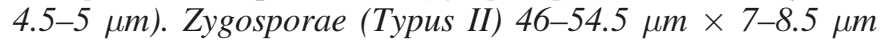
ad zygosporophorum oblique et submedie prope extremitatem sporae affixae, collo brevi ubi liberatae. In proctodaeo nympharum ephemerellidarum.

Thallus usually with two successive swollen basal cells 20-30 $\mu \mathrm{m} \times 7-9 \mu \mathrm{m}$, attached to the hindgut lining by cement secreted from the holdfast cell (Fig. 20). Branches from the basal cells further branch, bearing spores distally (Fig. 18). Trichospores slightly obpyriform, no collar, 20$26.5 \mu \mathrm{m} \times 4.5-6 \mu \mathrm{m}$, bearing three thick appendages equal in length (Fig. 19). Six to eight generative cells per fertile branch with each generative cell at least half the length of the trichospore. Conjugation between adjacent hyphae results in a swollen cell from which the zygosporophore (13-17 $\mu \mathrm{m} \times 4.5-5 \mu \mathrm{m})$ arises. Zygospores (Type II) 46$54.5 \mu \mathrm{m} \times 7-8.5 \mu \mathrm{m}$, attached obliquely to the zygosporophore and submedially near the spore tip (Fig. 21), with a short collar $(3-5 \mu \mathrm{m})$ when released. In the hindgut of mayfly nymphs (Ephemerellidae).

ETYMology.: named after a friend and mentor of D.B.S., Dr. Norman Whitney. Coincidentally, this species was also collected from a river that runs through the town of Whitney, Ontario, just outside Algonquin Park.

HоLотуре: microscope slide ALG-4-2 prepared from the hindgut of an Ephemerella temporalis McDunnough nymph containing thalli and zygospores of Legeriosimilis whitneyi, collected on 5 May 2003 from ALG 4. Type deposited at DAOM (No. 240025).

PARATYPE: microscope slide ALG-4-1 prepared from the hindgut of an E. temporalis nymph containing trichospores, collected from ALG 4 on 5 May 2003. Paratype deposited at DAOM (No. 240022).

НАвітAт: this fungus was collected from the guts of E. temporalis nymphs from shallow, marshy standing waters at sites ALG 4, ALG 10, ALG 15, and ALG 19. It was also collected in the same host at site WHIT, a fast-flowing river in the town of Whitney, just outside Algonquin Park.

COMMENTARY: six harpellid genera have trichospores, which can have three appendages, Ephemerellomyces, Harpella, Harpellomyces, Legeriosimilis, Pseudoharpella, and Stipella (Lichtwardt 2004). Of these, only Ephemerellomyces and Legeriosimilis have obpyriform trichospores with three ap- pendages, like L. whitneyi. There are currently two described species in Legeriosimilis: L. tricaudata (type species) and L. europaeus (Lichtwardt 2004). The trichospores in L. whitneyi are smaller $(20-26.5 \mu \mathrm{m} \times 4.5-6 \mu \mathrm{m})$ than in L. tricaudata $(33-52 \mu \mathrm{m} \times 7-11 \mu \mathrm{m})$ or L. europaeus $(33-40 \mu \mathrm{m} \times 6-8 \mu \mathrm{m})$, and there are no knobs on the appendages of L. whitneyi like those reported for the other two species (Lichtwardt 2004). Zygospores of L. whitneyi $(46-54.5 \mu \mathrm{m} \times 7-8.5 \mu \mathrm{m})$ overlap in length slightly with those of L. tricaudata $(52-58 \mu \mathrm{m} \times 11-13 \mu \mathrm{m})$, but are narrower. The trichospores of the monotypic Ephemerellomyces aquilonius M.M. White \& Lichtw. are similar in shape and can have three appendages like $L$. whitneyi, but the trichospores are wider $(30-50 \mu \mathrm{m} \times 8-10 \mu \mathrm{m})$ in E. aquilonius. Additionally, E. aquilonius can produce new thalli from trichospores released within the gut where they are produced (White and Lichtwardt 2004), but this phenomenon was not seen in nymphs containing L. whitneyi. Compared with $L$. leptocerci, described above, L. whitneyi differs by having smaller zygospores and broader appendages on the trichospores.

Paramoebidium umbonatum Strongman et M.M. White sp. nov., Figs. 22 and 23

Thallus simplex 200-300 $\mu \mathrm{m} \times 8-22 \mu \mathrm{m}$, interius ad proctodaeum haptero basali gongylode conspicuo affixus. Thallus prope basin recurvatus, cum protuberatione in latere extero flexus. Pars distalis thalli tumida, papillam parvam $(6-12 \mu \mathrm{m})$ ferens. Interius ad proctodaeum nympharum leptophlebiidarum affixus.

Thallus unbranched 200-300 $\mu \mathrm{m} \times 8-22 \mu \mathrm{m}$, attached to hindgut lining by a conspicuous knob-like, basal holdfast (Fig. 22). Thallus recurved near the base, with a protuberance on the outer side of the bend. The distal end of the thallus is swollen, with a small papilla $(6-12 \mu \mathrm{m})$ (Fig. 22). Attached to hindgut lining of mayfly nymphs (Leptophlebiidae).

ETYMOLOGY: from the Latin umbo in reference to the rounded protuberance near the base of the thallus.

HOLOTYPE: microscope slide ALG-1-2 prepared from the hindgut of a mayfly nymph Haprophlebia vibrans Needham (Leptophlebiidae) collected on 5 May 2003. Type deposited at DAOM (No. 240024).

навітAт: this protistan trichomycete was collected from $\mathrm{H}$. vibrans nymphs from a fast-flowing stream (ALG 1) where the outflow from Costello Lake runs through a culvert under Opeongo Road in Algonquin Park.

COMMENTARY: there are only two other species of Paramoebidium that have a papilla on the thallus, Paramoebidium argentinense Mazzucchelli, López Lastra, \& Lichtw. from baetid mayflies in Argentina and Paramoebidium papillatum Lichtw. \& M.C. Williams from siphlonurid mayflies in New Zealand (Lichtwardt 2004). Neither of these species have recurved thalli with a protuberance like Paramoebidium umbonatum. The thallus in $P$. argentinense is swollen in the middle and $P$. papillatum has a lateral holdfast that is located $1 / 5$ to $1 / 3$ from the end of the thallus, which provides clear characters to separate these three species.

Pennella digitata Strongman et M.M. White sp. nov., Figs. 24-29

Thallus ex axe centrali crasso dense regulariterque ramo- 
Figs. 18-21. Legeriosimilis whitneyi. Fig. 18. Detached thallus bearing zygospores and trichospores. Fig. 19. Mass of detached trichospores, each with 3 appendages (arrowheads). Fig. 20. Base of thallus showing a holdfast (arrow) with secreted material around a swollen basal cell. Fig. 21. Zygospore (Type II) still attached to the zygosporophore near one end of the spore. All figures show lactophenol - cotton bluestained specimens. Scale bars $=20 \mu \mathrm{m}$.

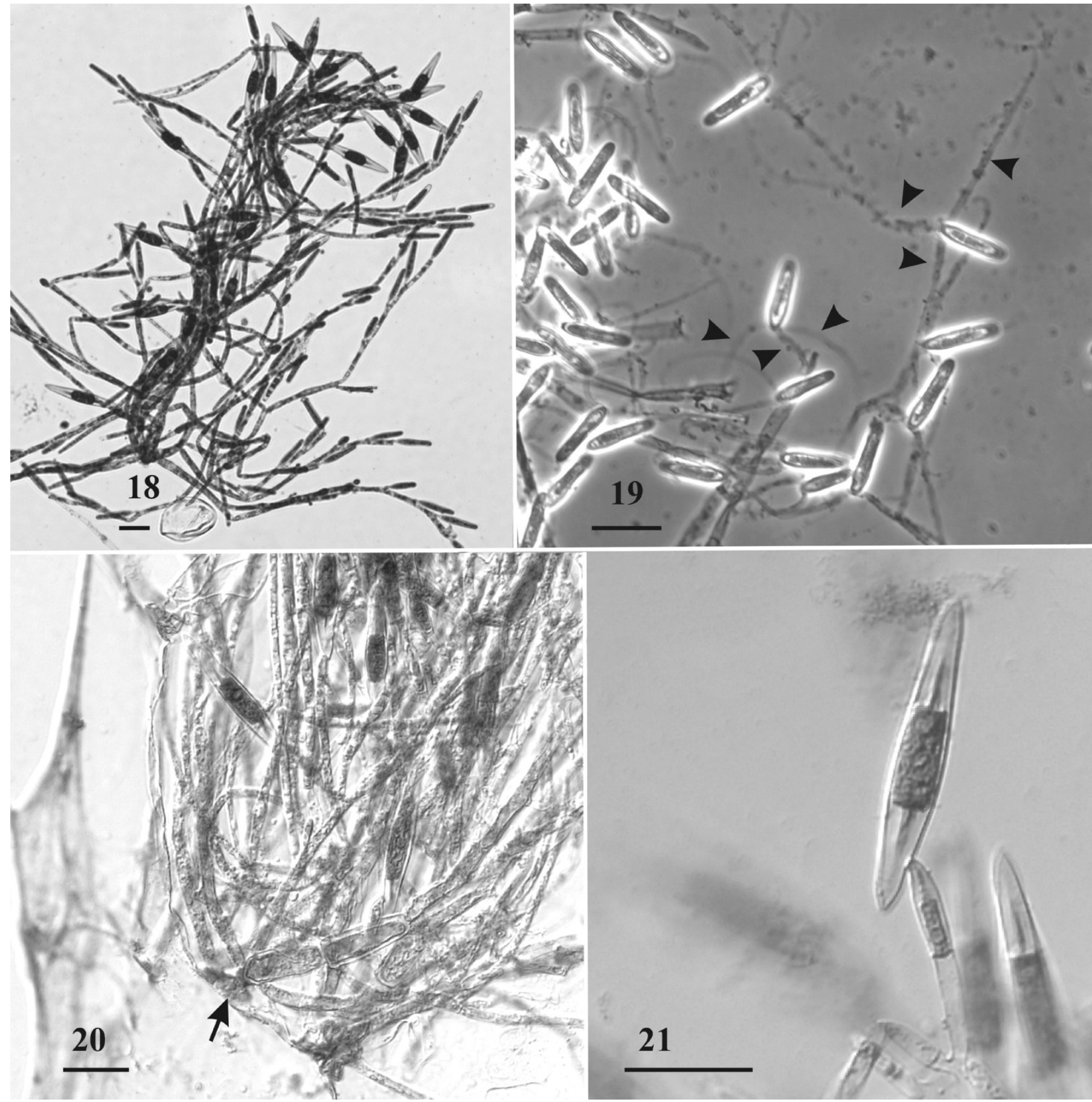

sus; hapteron digitatum, bifurcationibus profundis, secretione mucilagina circumcinctum. Rami laterales ab axe centrali et projecturis digitiformibus hapteri perpendiculariter emergentes. Trichosporae longi-ovoideae 27.5-33.5 $\mu \mathrm{m} \times$ 6.5-8 $\mu \mathrm{m}$, sine collo, circa sex appendicibus tenuibus instructae. Zygosporae (Typi III) (37-)40-44 $\mathrm{mm} \times 1 \mathrm{I}_{-}$ $13.5 \mu \mathrm{m}$, ad zygosporophora 28.5-31 $\mu \mathrm{m} \times 8.5-11 \mu \mathrm{m}$, parallelae portatae. In proctodaeo larvarum simuliidarum.
Thallus densely and regularly branched from a stout central axis (Figs. 24, 26, and 27), holdfast digitate with deep bifurcations and surrounded by a mucilaginous secretion (Fig. 26). Lateral branches emerging at right angles from both the central axis of the thallus and the finger-like projections of the holdfast (Fig. 27). Trichospores are long-ovoid 27.5-33.5 $\mu \mathrm{m} \times 6.5-8 \mu \mathrm{m}$ (Fig. 29), no collar, commonly with 6 fine appendages. Zygospores (Type III) (37-)40- 
Figs. 22 and 23. Paramoebidium umbonata. Fig. 22. Unbranched thalli attached to the gut lining by a conspicuous, knob-like, glued holdfast (arrowhead). Note the protuberance near the holdfast (small arrow) and a prominent papilla at the distal tip of the thallus (large arrow). Fig. 23. Empty thallus with encysted amoeba near the tip. Figs. 22 and 23 are from lactophenol - cotton blue-stained specimens. Scale bars $=20 \mu \mathrm{m}$.

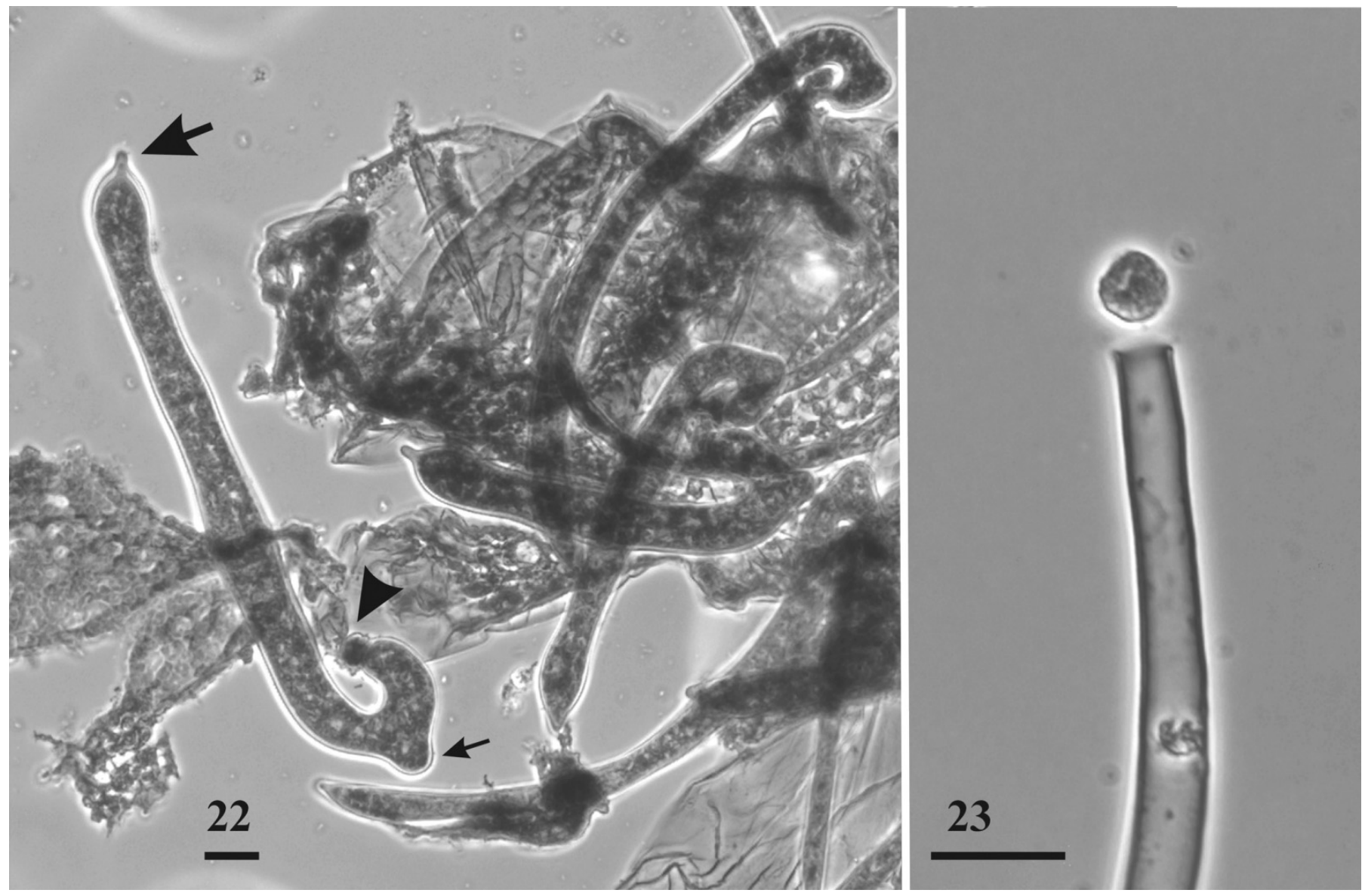

$44 \mu \mathrm{m} \times 10-13.5 \mu \mathrm{m}$ (Fig. 25), borne parallel to the zygosporophores 28.5-31 $\mu \mathrm{m} \times 8.5-11 \mu \mathrm{m}$ (Fig. 28). In the hindgut of black fly larvae (Simuliidae).

ETYMOLOGY: from the Latin digitatus meaning having fingers, in reference to the prominent finger-like projections of the holdfast in this species.

HOLOTYPE: microscope slide ALG-3-5 prepared from the hindgut of a black fly larva (Simuliidae) collected on 3 May 2003. Type deposited at DAOM (No. 240023).

НАвІтАт: this fungus was collected from black fly larvae at the fast flowing outlet of a beaver pond adjacent to Opeongo Road in Algonquin Park (ALG 3) in 2003 and in the pond (ALG 10), near the outlet, in the 2004 collections.

COMmEntary: only two genera of trichomycetous fungi, Genistellospora and Pennella, have Type III zygospores that form parallel to the zygosporophore (Lichtwardt 2004). Members of these two genera share many features but are separated primarily on holdfast characteristics with species of Pennella having tapered, bifurcate, or nearly digitate holdfasts embedded in mucilage, while those of Genistellospora are not tapered or branched and are cemented to the gut lining of their black fly hosts (Lichtwardt 2004). Pennella hovassi Manier ex Manier was described from France and reported by Frost and Manier (1971) from black fly larvae from
Newfoundland and possibly recovered by Beard and Adler (2002) from South Carolina (as Pennella near hovassi). This species has a deeply and repeatedly bifurcated holdfast as in Pennella digitata, but the trichospores are strongly obpyriform and the zygospores are much larger $(68-79 \mu \mathrm{m} \times$ 7.5-13 $\mu \mathrm{m}$ ) (Lichtwardt 2004) than those in P. digitata (40-44 $\mu \mathrm{m} \times 10-13.5 \mu \mathrm{m})$. The zygosporophore dimensions for $P$. hovassi are in the same range, $25-30 \mu \mathrm{m} \times 8-12 \mu \mathrm{m}$, as $P$. digitata $(28.5-31 \mu \mathrm{m} \times 8.5-11 \mu \mathrm{m})$, but the terminal cell of the zygosporophore is strongly clavate in $P$. hovassi (Frost and Manier 1971). Another species, Pennella arctica Lichtw. \& M.C. Williams, has a deeply bifurcated holdfast, but the zygospores $(65-72 \mu \mathrm{m} \times 15-18 \mu \mathrm{m})$, the zygosporophores $(35-40 \mu \mathrm{m} \times 13-20 \mu \mathrm{m})$ and the trichospores $(40$ $58 \mu \mathrm{m} \times 8-11 \mu \mathrm{m})($ Lichtwardt 1984) are much larger than in $P$. digitata. Pennella simulii M.C. Williams \& Lichtw., which inhabits the guts of black flies, is widely distributed (Lichtwardt 2004). It was common at sites in Ontario where simuliids were collected (Table 2), has been reported from Newfoundland (Lichtwardt et al. 2001b), Nunavut (Kim and Adler 2005) and is also known from NS, New Brunswick and British Columbia (D.B.S., unpublished data, 20022006). The holdfast in $P$. simulii is elongated, sometimes divided, and the trichospores and zygospores are larger (Lichtwardt 2004) than in P. digitata. 
Figs. 24-29. Pennella digitata. Fig. 24. Thallus with biconical zygospores (small arrows), a trichospore (filled arrowhead), and digitate holdfast (arrow). Also note smaller trichospores of Simuliomyces microsporus Lichtw. (open arrowhead). Fig. 25. Released zygospore with zygosporophore attached. Fig. 26. Deeply divided and bifurcated holdfast detached from the gut lining but with secreted mucilage visible (arrow). Fig. 27. Digitate holdfast (arrow) and basal part of the thallus with branches arising at right angles (arrowhead). Fig. 28. Zygospores (Type III) attached medially and parallel to the zygosporophore (arrowheads). Trichospores of S. microsporus (arrow) are interspersed. Fig. 29. Developing thallus with digitate holdfast (arrow) and trichospore (arrowhead). Fig. 27 is from living material, all others are stained with lactophenol - cotton blue. Scale bars $=20 \mu \mathrm{m}$.

OTHER SPECIES: Legeriomyces rarus was described from Australia (Williams and Lichtwardt 1993) and subsequently reported in Spain by Valle and Santamaria (2004). Both papers report the occurrence of this fungus as rare at the respective sites. This species was collected at one site in Ontario and only 2 out of 7 mayflies collected at this site contained $L$. rarus, although the host was abundant at other sites. Therefore, our data support the concept that this fungus is rare, but apparently widely distributed, having been reported only once from each of three countries on separate continents.

Stachylina penetralis was recorded from Asia (China and Japan), France and Switzerland (Lichtwardt 2004). It is reported here as a new continental record from the gut of a chironomid larva collected at ONT 4. However, D.B.S. (unpublished data, 2002-2008) has also seen this species in several collections from eastern Canada. The larva containing $S$. penetralis also had Smittium alpinum Lichtw. in the hindgut, previously reported in North America only from Montana but also collected in Sweden and from the French and Swiss Alps (Lichtwardt 2004).

In addition to $S$. alpinum, five other fungal species and one protistan trichomycete collected in Ontario are first records for Canada (Table 2). The harpellid fungi are Genistellospora homothallica Lichtw., Graminella microspora S.T. Moss \& Lichtw., Smittium culisetae, Smittium mисronatum Manier \& Mathiez ex Manier, and one Asellariales, Orchesellaria sp., was found. The protist, Enterobryus euryuri Lichtw. is also a new Canadian record. Until this report, three other Harpellales, Harpellomyces abruptus Lichtw., M.M. White, \& Colbo, Orphella avalonensis Lichtw., M.M. White, \& Colbo, and Smittium insulare Strongman, were known only from Atlantic Canada, while nine other species found in Ontario were collected previously in eastern Canada (Table 2).

Orphella avalonensis collected in Ontario showed some morphological variation compared with the type material from Newfoundland (Lichtwardt et al. 2001b) and subsequent collections made in Nova Scotia (Strongman and White 2006). Using the terminology established by Valle and Santamaria (2005), the basal cell from which the trichospore and accessory cells are produced is tubular or slightly clavate in the type material of $O$. avalonensis (Figs. 30 and 31). The basal cells observed in collections from Nova Scotia were similar to the type, but thalli showing strongly clavate basal cells were also seen in the gut of the same stonefly (Fig. 32). The basal cells of $O$. avalonensis in the Ontario collections were strongly clavate (Fig. 33). All other features, such as the holdfast, trichospore, generative and subgenerative cells, and terminal cell dimensions, were within the range for $O$. avalonensis for the collections both from Ontario and Nova Scotia.
We also collected a species of Legeriomyces from trichopteran hosts, a species of Austrosmittium from chironomids, and a species of Orphella resembling Orphella catalaunica Santamaria \& Girbal, but these will be incorporated into other reports addressing these species in a broader context.

\section{Discussion}

The trichomycete diversity in Algonquin Park was high, with 23 of the 32 species collected from 11 sites within the Park boundaries. Six of the seven newly described species also came from within the Park, however, the prevalence of trichomycetes here could simply reflect our increased sampling effort inside the park. Collections were made at six sites in Ontario, outside Algonquin Park, including three waterfall splash zones or seep habitats. Of the nine species found outside Algonquin Park, one new species was recorded (Table 2).

Algonquin Park has a variety of aquatic habitats and many of these are lentic systems (lakes and standing or slow-moving water courses). Other trichomycete studies have included collections from lentic habitats, but the focus has been mostly on mosquito larvae in these systems (Lichtwardt 1986; Lichtwardt et al. 2001a). We examined a variety of hosts, mostly dipteran larvae and mayflies, some that are specific to lentic habitats, as well as others that are found in both lentic and lotic systems (Merritt and Cummins 1996) and found five trichomycete species in hosts normally found in lentic habitats. Of these, two were new species, A. opeongoensis and $G$. incilis. We suggest that trichomycete diversity is rich in lentic systems and more collections will continue to increase our knowledge of gut endobionts in these habitats.

Host diversity was low in seep habitats (rock cuts and waterfall splash zones), but some insects found here are adapted specifically to these unique habitats so their distribution is, therefore, restricted. Interestingly, Smittium culicis Manier was common in dipteran hosts at all five sites of this type sampled in Ontario. One of these hosts was soldier fly (Stratiomyidae) larvae, which have not been reported, until now, as a host for trichomycetes. Trichomycetes have been recorded from dipteran hosts belonging to the Nematocera, so it is also worthwhile noting that this published record from a stratiomyid fly is the first, to our knowledge, from flies in the suborder Brachycera. Smittium culicis is globally distributed and is found in a variety of dipteran hosts, including mosquitoes from lentic habitats (Lichtwardt et al. 2001a). The occurrence of trichomycetes in these specific and often isolated (from other water sources) habitats and the mechanism by which they are distributed is intriguing. 


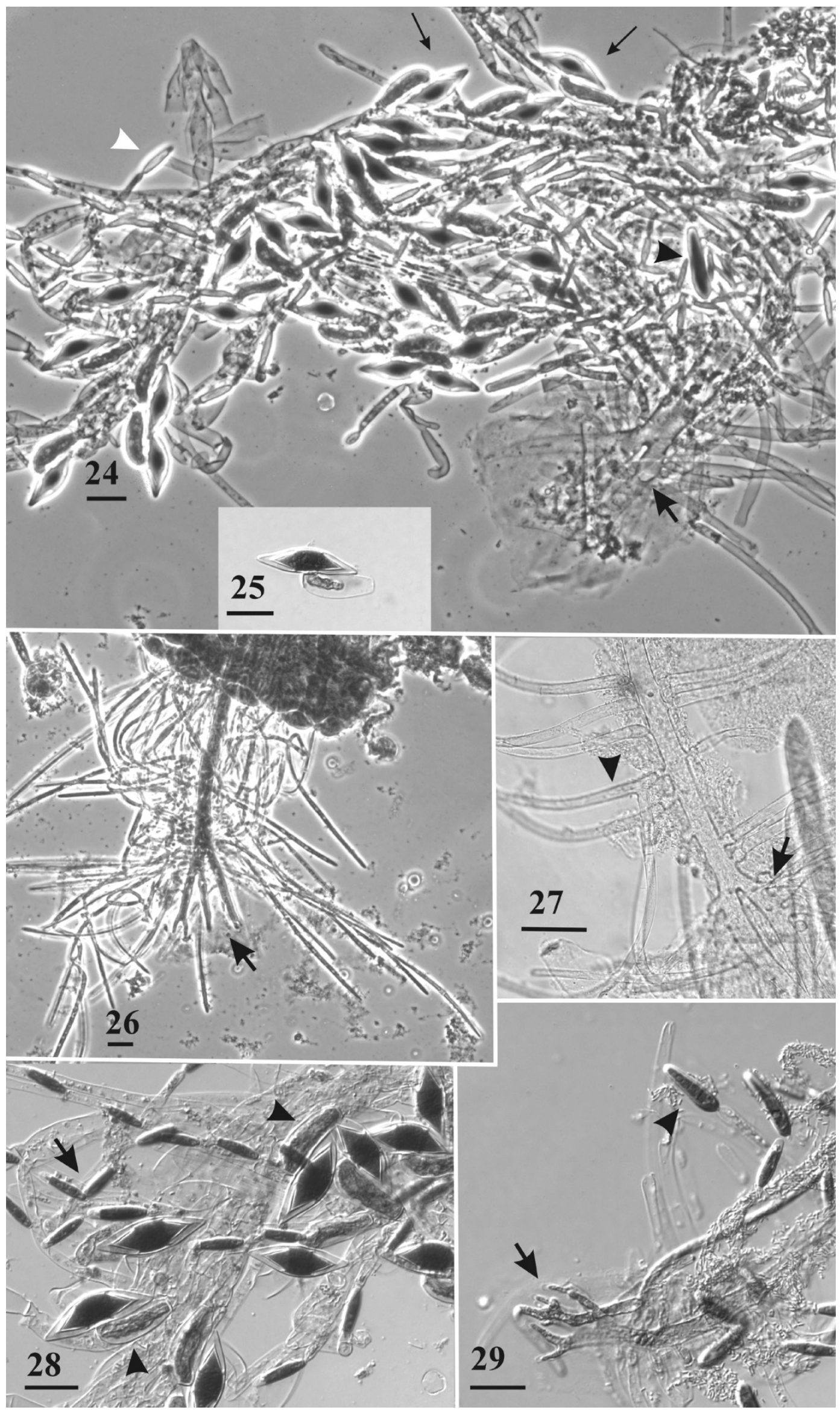


Figs. 30-33. Orphella avalonensis. Fig. 30. Sporulating heads on type slide (NF-3-W7) from the Farlow Herbarium (FH). Fig. 31. Type slide showing slightly clavate basal cell (arrow) with two asexual dissemination units (trichospores) attached. Fig. 32. Specimens from Nova Scotia (slide ANT3-3, 9 August 2007). Note both cylindrical (arrow) and clavate (arrowhead) basal cells on separate thalli. Fig. 33. Specimen from Ontario (slide ALG-21-W1) with strongly clavate basal cells (arrowhead). All figures are of lactophenol - cotton blue-stained specimens. Scale bars $=20 \mu \mathrm{m}$.
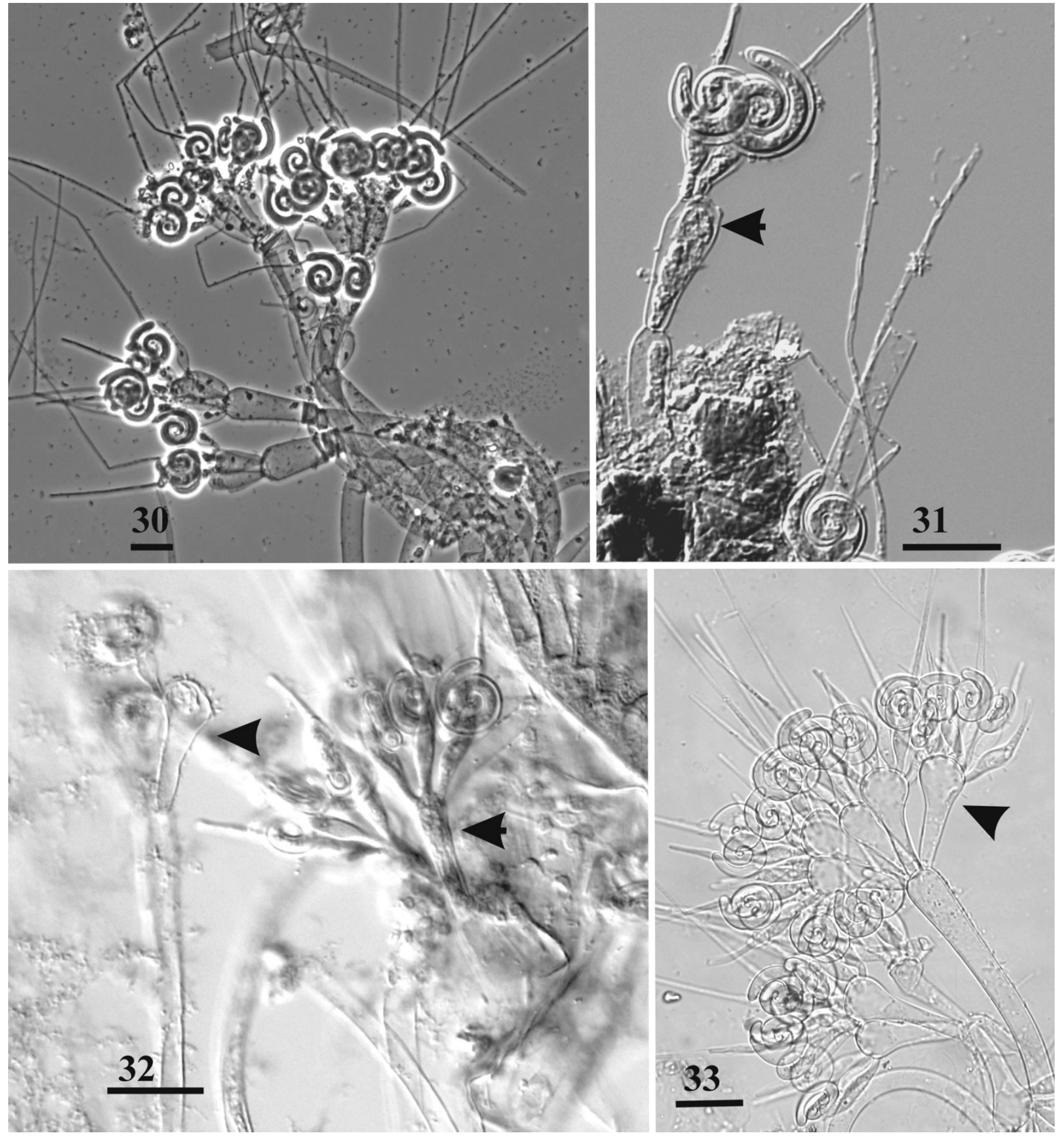

One method could be transovarial transmission, as described for H. melusinae, Smittium simulii Lichtw., and G. homothallica in black fly larvae in lotic systems (Moss and Descals 1986; Labeyrie et al. 1996; White et al. 2006a).
Table 2 shows the distribution of species recovered from arthropods in Ontario. This list includes many species that occur on three or more continents, e.g., G. homothallica, H. melusinae, S. microsporus, S. culicis, S. culisetae, and 
Smittium grandispora Lichtw. (Lichtwardt et al. 2001a). Most of these were found in dipteran hosts, so our findings from central Canada support the hypotheses about the biogeography and distribution mechanisms for trichomycetes described by Lichtwardt (1995) and Adler et al. (2005). We found one caenid mayfly nymph with $L$. rarus in the hindgut. This fungus has been collected in caenids in Australia (Williams and Lichtwardt 1993) and Spain (Valle and Santamaria 2004). It seems that L. rarus, although rare, is widely distributed in mayflies. Therefore, there may be unknown mechanisms for long-range dispersal of hosts with low vagility, or these fungi migrated into streams with their hosts as glaciers retreated after the last ice age, as suggested by Lichtwardt (1995).

The specimens of $O$. avalonesis collected in Algonquin Park fit the species description, based on thallus and trichospore features, but the conspicuous apical swelling of the basal cells varied markedly from the morphology of these cells in the type specimen (Figs. 30-33). Overlap in key morphological features, such as trichospore length and width, is well documented for trichomycetous fungi (Lichtwardt et al. 2001a), so we examined the type material for $O$. avalonensis and also reviewed collections from Nova Scotia and Newfoundland to assess variability in the basalcell shape. The clavate basal cells in specimens from Nova Scotia and Ontario had many more trichospores attached or released than did specimens with nonclavate basal cells. It is possible that the variation in morphology that we observed is developmental in nature, related to the number of trichospores produced per basal cell and (or) spore-head development. In thalli that are sporulating profusely, or as the spore head matures, perhaps the basal cells swell at the apex to accommodate the production of many trichospores? If this conjecture is true, it will be important to consider variation due to developmental changes when identifying and describing species. To confirm these speculations, further collections of $O$. avalonensis in different stages of maturation of the spore head are needed to determine whether the morphology of the basal cell is variable according to trichospore number and maturity.

This study presents data from a survey of trichomycetes at 11 sites in Algonquin Park. The sites sampled were a small proportion of the large number and variety of aquatic habitats in the Park (and the province) so future collections at different times (seasons) and in different habitats will no doubt yield other hosts with trichomycetes, including new species that remain undiscovered in Canada.

\section{Acknowledgments}

We thank Dr. Nelson Watson (Associate, Nova Scotia Museum of Natural History, Halifax, N.S.); Dr. Murray Colbo (Coldbrook, N.S.); Dr. Richard Hoffman, Virginia Museum of Natural History, Martinsville, Virginia,; and Dr. George Byers, University of Kansas Museum of Natural History, Lawrence, Kansas; and Dr. Brad Sinclair, Canadian National Collection of Insects Arachnids and Nematodes, Ottawa, Ontario, for identification of some insect hosts. We also thank Dr. Steve Marshall and John Klymkos, University of Guelph, Guelph, Ontario, who assisted in collections outside Algonquin Park and for identification of some insects.
Carolyn Bird provided the Latin diagnoses and many valuable comments on the descriptions and language regarding the new species described herein. John Winters, Park Superintendent, Whitney, Ontario, kindly reviewed our proposal and granted permission to make collections in Algonquin Park. The staff at the Harkness Laboratory of Fisheries Research, Algonquin Park, provided helpful suggestions on sites and a comfortable environment for conducting the survey. Financial support was provided by a National Science Foundation (NSF), Biodiversity Surveys and Inventory award DEB-0344722, (M.M.W., P.I.), which also provided support to D.B.S. (as a formal collaborator) toward surveys done in Canada. Any opinions, findings, and conclusions or recommendations expressed in this material are those of the authors and do not necessarily reflect the views of NSF. Saint Mary's University Faculty of Graduate Studies and Research also provided travel funds to D.B.S. for these studies.

\section{References}

Adler, P.H., Giberson, D.J., and Purcell, L.A. 2005. Insular black flies (Diptera: Simuliidae) of North America: tests of colonization hypotheses. J. Biogeogr. 32: 211-220. doi:10.1111/j.13652699.2004.01156.x.

Beard, C.E., and Adler, P.H. 2002. Seasonality of trichomycetes in larval black flies from South Carolina, USA. Mycologia, 94: 200-209. doi:10.2307/3761796.

Davies, D.M. 1952. The population and activity of adult female black flies in the vicinity of a stream in Algonquin Park, Ontario. Can. J. Zool. 30: 287-321. doi:10.1139/z52-027.

Environment Canada. Hydrology of Canada. [Last updated 16 June 2004]. Available from www.wsc.ec.gc.ca/hydrology/main_e. cfm?cname=hydro_e.cfm\# [accessed 24 October 2008].

Frost, S., and Manier, J.-F. 1971. Notes on Trichomycetes (Harpellales: Harpellaceae and Genistellaceae) in larval blackflies (Diptera: Simuliidae) from Newfoundland. Can. J. Zool. 49: 776778. doi:10.1139/z71-114.

Hall, R.J., and Ide, F.P. 1987. Evidence of acidification effects on stream insect communities in central Ontario between 1937 and 1985. Can. J. Fish. Aquat. Sci. 44: 1652-1657. doi:10.1139/f87-201.

Harkness Laboratory of Fisheries Research. 1930-2009. Publications. Available from www.harkness.ca/journal_pub.htm [accessed 24 October 2008].

Hibbett, D.S., Binder, M., Bischoff, J.F., Blackwell, M., Cannon, P.F., Eriksson, O.E., Huhndorf, S., James, T., Kirk, P.M., Lücking, R., Thorsten Lumbsch, H., Lutzoni, F., Matheny, P.B., McLaughlin, D.J., Powell, M.J., Redhead, S., Schoch, C.L., Spatafora, J.W., Stalpers, J.A., Vilgalys, R., Aime, M.C., Aptroot, A., Bauer, R., Begerow, D., Benny, G.L., Castlebury, L.A., Crous, P.W., Dai, Y.-C., Gams, W., Geiser, D.M., Griffith, G.W., Gueidan, C., Hawksworth, D.L., Hestmark, G., Hosaka, K., Humber, R.A., Hyde, K.D., Ironside, J.E., Köljalg, U., Kurtzman, C.P., Larsson, K.-H., Lichtwardt, R.W., Longcore, J., Miadlikowska, J., Miller, A., Moncalvo, J.-M., MozleyStandridge, S., Oberwinkler, F., Parmasto, E., Reeb, V., Rogers, J.D., Roux, C., Ryvarden, L., Sampaio, J.P., Schüjler, A., Sugiyama, J., Thorn, R.G., Tibell, L., Untereiner, W.A., Walker, C., Wang, Z., Weir, A., Weiss, M., White, M.M., Winka, K., Yao, Y.-J., and Zhang, N. 2007. A higher-level phylogenetic classification of the Fungi. Mycol. Res. 111: 509-547. doi:10.1016/j.mycres.2007.03.004.

Kim, S.-K., and Adler, P.H. 2005. Multiple symbiotes in larval black flies (Diptera: Simuliidae): associations of trichomycete 
fungi with ichthyosporeans, mermithid nematodes, and microsporidia. J. Invertebr. Pathol. 88: 247-253. doi:10.1016/j.jip. 2005.02.005. PMID:15955344.

Kim, S.-K., and Adler, P.H. 2007. Size variation of trichospores of Harpella melusinae in larval black flies. Mycologia, 99: 351355. doi:10.3852/mycologia.99.3.351. PMID:17883026.

Labeyrie, E.S., Molloy, D.P., and Lichtwardt, R.W. 1996. An investigation of Harpellales (Trichomycetes) in New York State blackflies (Diptera: Simuliidae). J. Invertebr. Pathol. 68: 293298. doi:10.1006/jipa.1996.0099. PMID:8954818.

Lichtwardt, R.W. 1984. Species of Harpellales living within the guts of aquatic Diptera larvae. Mycotaxon, 19: 529-550.

Lichtwardt, R.W. 1986. The Trichomycetes: Fungal associates of arthropods. Springer-Verlag, New York, N.Y.

Lichtwardt, R.W. 1995. Biogeography and fungal systematics. Can. J. Bot. 73(Suppl. 1): S731-S737. doi:10.1139/b95-316.

Lichtwardt, R.W. 2004. Lucid keys to the Trichomycetes [Online]. Available from www.nhm.ku.edu/ fungi/Lucid\%20Keys.html [accessed 29 July 2008].

Lichtwardt, R.W., and Williams, M.C. 1983. A new Legeriomyces (Harpellales) with variable trichospore size. Mycologia, 75: 757-761. doi:10.2307/3792767.

Lichtwardt, R.W., Cafaro, M., and White, M.M. 2001a. The Trichomycetes: Fungal associates of arthropods. [Online] Available from www.nhm.ku.edu/\%7Efungi/Monograph/Text/Mono.htm [accessed 29 July 2008].

Lichtwardt, R.W., White, M.M., and Colbo, M.H. 2001b. Harpellales in Newfoundland aquatic insect larvae. Mycologia, 93: 764-773. doi:10.2307/3761832.

Merritt, R.W., and Cummins, K.W. 1996. An introduction to the aquatic insects of North America. 3rd ed. Kendall/Hunt Pubishing Co., Dubuque, Iowa.

Moss, S.T., and Descals, E. 1986. A previously undescribed stage in the life cycle of Harpellales (Trichomycetes). Mycologia, 78: 213-222. doi:10.2307/3793166.

Nelder, M.P., Beard, C.E., Adler, P.H., Kim, S.-K., and McCreadie, J.W. 2006. Harpellales (Zygomycota: Trichomycetes) associated with black flies (Diptera: Simuliidae): world review and synthesis of their ecology and taxonomy. Fungal Divers. 22: 121-169.

Runtz, M. 2008. The explorer's guide to Algonquin Park. Boston Mills Press, Erin, Ont.
SBAA. 2004-2005. The science behind Algonquin's animals: introduction to Algonquin. Available from www.sbaa.ca/about. asp?n=278\&o=1 [accessed 24 October 2008].

Sprules, W.M. 1947. An ecological investigation of stream insects in Algonquin Park, Ontario. University of Toronto Studies, Biological Series No. 56. Publication of the Ontario Fisheries Laboratory 69 .

Strongman, D.B. 2007. Trichomycetes in aquatic insects from Prince Edward Island, Canada. Can. J. Bot. 85: 949-963. doi:10.1139/b07-095.

Strongman, D.B., and White, M.M. 2006. New species of Lancisporomyces, Orphella, and Paramoebidium, endosymbionts of stonefly nymphs from stream in Nova Scotia, Canada. Can. J. Bot. 84: 1478-1495. doi:10.1139/B06-107.

Valle, L.G., and Santamaria, S. 2004. Bojamyces transfuga sp. nov., and new records of Trichomycetes from mayfly larvae in Spain. Mycologia, 96: 1386-1392. doi:10.2307/3762155.

Valle, L.G., and Santamaria, S. 2005. Zygospores as evidence of sexual reproduction in the genus Orphella. Mycologia, 97: 1335-1347. doi:10.3852/mycologia.97.6.1335. PMID:16722224.

Valle, L.G., White, M.M., and Cafaro, M.J. 2008. Harpellales in the digestive tracts of Ephemeroptera and Plecoptera nymphs from Veracruz, Mexico. Mycologia, 100: 149-163. doi:10.3852/ mycologia.100.1.149. PMID:18488361.

White, M.M., and Lichtwardt, R.W. 2004. Fungal symbionts (Harpellales) in Norwegian aquatic insect larvae. Mycologia, 96: 890-910. doi:10.2307/3762122.

White, M.M., Lichtwardt, R.W., and Colbo, M.H. 2006a. Confirmation and identification of parasitic stages of obligate endobionts (Harpellales) in blackflies (Simuliidae) by means of rRNA sequence data. Mycol. Res. 110: 1070-1079. doi:10. 1016/j.mycres.2006.06.008. PMID:16930974.

White, M.M., Siri, A., and Lichtwardt, R.W. 2006b. Trichomycete insect symbionts in Great Smoky Mountains National Park and vicinity. Mycologia, 98: 333-352. doi:10.3852/mycologia.98.2. 333. PMID:16894978.

Williams, M.C., and Lichtwardt, R.W. 1993. A new monotypic fungal genus, Allantomyces, and a new species of Legeriomyces (Trichomycetes, Harpellales) in the hindgut of a Western Australian mayfly nymph (Tasmanocoenis sp.). Can. J. Bot. 71: 1109-1113. doi:10.1139/b93-130. 